\title{
Cerebrovascular reactivity to carbon dioxide is preserved during hypocapnia in children anes- thetized with 1.0 MAC, but not with 1.5 MAC desflurane
}

\author{
[La réactivité cérébrovasculaire au gaz carbonique est conservée pendant l'hypocapnie \\ chez des enfants anesthésiés avec 1,0 CAM, mais non avec 1,5 CAM, de desflurane]
}

Igor A. Luginbuehl MD, Cengiz Karsli BSc MD FRCPC, Bruno Bissonnette BSc MD FRCPC

Purpose: Maintenance of cerebrovascular reactivity to $\mathrm{CO}_{2}$ $\left(\mathrm{CCO}_{2} \mathrm{R}\right)$ is important during neurosurgical anesthesia. This study was designed to determine the effect of different desflurane concentrations on $\mathrm{CCO}_{2} \mathrm{R}$ in children.

Methods: Children undergoing urological surgery were enrolled. Anesthesia was induced with sevoflurane in air/oxygen. After intubation, sevoflurane was switched to desflurane. Analgesia was provided with an epidural neuraxial block. Mechanical ventilation was adjusted to an initial $\mathrm{EtCO}_{2}$ of $30 \mathrm{mmHg}$. Exogenous $\mathrm{CO}_{2}$ was used to achieve an $\mathrm{EtCO}_{2}$ of 40 and $50 \mathrm{mmHg}$. Patients were randomized to the sequence of desflurane concentration ( 1.0 and 1.5 $\mathrm{MAC}$ ) and the $\mathrm{EtCO}_{2}$. Transcranial Doppler was used to measure middle cerebral artery blood flow velocity (Vmca). Five minutes were allowed to reach steady state after each change in $\mathrm{EtCO}_{2}$ and I 5 min after changing the desflurane concentration.

Results: Sixteen patients were studied. The mean age and weight were $3.5 \pm 1.5 \mathrm{yr}$ and $14.4 \pm 3.1 \mathrm{~kg}$, respectively. Mean arterial pressure remained stable throughout the study, while at an $\mathrm{EtCO}_{2}$ of $50 \mathrm{mmHg}$, heart rate decreased at both desflurane concentrations $(P<0.05)$. At I.0 MAC, Vmca increased from 30 to 40 $\mathrm{mmHg}(P<0.05)$, but not from 40 to $50 \mathrm{mmHg} \mathrm{EtCO}_{2}$. At 1.5 MAC, Vmca increased between 30 and $50 \mathrm{mmHg}(P<0.05)$.

Conclusion: $\mathrm{CCO}_{2} \mathrm{R}$ is preserved during hypocapnia in children anesthetized with I.0 MAC, but not with I.5 MAC desflurane. The lack of further increase in $\mathrm{Vmca}$ at higher $\mathrm{EtCO}_{2}$ concentrations implies that desflurane may cause significant cerebral vasodilatation in children. This may have important implications in children with reduced intracranial compliance.
Objectif : Le maintien de la réactivité cérébrovasculaire au $\mathrm{CO}_{2}$ $\left(\mathrm{RCCO}_{2}\right)$ est important pendant l'anesthésie neurochirurgicale. Nous voulions déterminer l'effet de différentes concentrations de desflurane sur la $\mathrm{RCCO}_{2}$ chez des enfants.

Méthode : Les enfants choisis devaient subir une intervention urologique. L'anesthésie a été induite avec du sévoflurane dans un mélange d'air et d'oxygène. Après l'intubation, le sévoflurane a été remplacé par du desflurane. L'analgésie a été prodiguée par un bloc neuraxial péridural. La ventilation mécanique a été réglée selon un EtCO $\mathrm{CO}_{2}$ initial de $30 \mathrm{mmHg}$. Du $\mathrm{CO}_{2}$ exogène a permis d'obtenir un $\mathrm{EtCO}_{2}$ de 40 et $50 \mathrm{mmHg}$. Les patients, répartis au hasard, ont reçu la séquence de desflurane ( 1,0 et I,5 CAM) et de $\mathrm{EtCO}_{2}$. La vitesse circulatoire de l'artère cérébrale moyenne (Vacm) a été mesuré par Doppler transcrânien. L'état d'équilibre a été atteint en 5 min après chaque changement de $\mathrm{EtCO}_{2}$ et 15 min après la nouvelle concentration de desflurane.

Résultats : L'étude a porté sur 16 patients. L'âge et le poids moyens étaient de 3,5 $\pm 1,5$ ans et 14,4 $\pm 3,1 \mathrm{~kg}$. La tension artérielle a été stable tout au long de l'étude, tandis que pour un $\mathrm{EtCO}_{2}$ de $50 \mathrm{mmHg}$, la fréquence cardiaque a diminué avec les deux concentrations de desflurane $(P<0,05)$. À I,0 CAM, la Vacm a augmenté pour un $\mathrm{EtCO}_{2}$ de 30 à $40 \mathrm{mmHg}(P<0,05)$, mais non de 40 à $50 \mathrm{mmHg}$. À I, 5 CAM, la Vacm s'est élevée entre 30 et $50 \mathrm{mmHg}(P<0,05)$.

Conclusion : La RCCO est conservée pendant l'hypocapnie chez des enfants anesthésiés avec 1,0 CAM, mais non avec 1,5 CAM, de desflurane. L'absence d'une nouvelle augmentation de la Vacm pour des concentrations plus élevées de EtCO ${ }_{2}$ sous-entend que le desflurane peut causer une vasodilatation cérébrale significative chez les enfants. Ce résultat peut avoir d'importantes implications chez les enfants qui présentent une compliance intracrânienne réduite.

From the Department of Anaesthesia, The Hospital for Sick Children, University of Toronto, Toronto, Ontario, Canada. Address correspondence to: Dr. Bruno Bissonnette, Department of Anaesthesia, The Hospital for Sick Children, 555 University Avenue, Toronto, Ontario M5G 1X8, Canada. Phone: 416-813-7445; Fax: 416-813-7543, E-mail: bruno@anaes.sickkids.on.ca

Presented in part at the Annual Meeting of the American Society of Anesthesiologists, October 13-17, 2001, New Orleans, USA. Accepted for publication July 12, 2002.

Revision accepted November 6, 2002. 


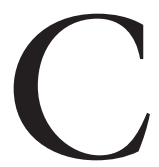

ARBON dioxide has a rapid and important influence on the cerebral vasculature. Rapid diffusion of $\mathrm{CO}_{2}$ from the arterial blood into the arteriolar smooth muscle cells generates a change in perivascular $\mathrm{pH}$, which is thought to be responsible for the maintenance of cerebrovascular reactivity to $\mathrm{CO}_{2}\left(\mathrm{CCO}_{2} \mathrm{R}\right) .{ }^{1}$ At hypocapnia, this results in reduced cerebral blood flow and cerebral blood volume and may be used to control the intracranial pressure (ICP).

The favourable physico-chemical properties of desflurane (low blood-gas and tissue solubility) make it a potentially suitable anesthetic agent for neuroanesthesia, allowing for rapid emergence and postoperative neurological assessment. Studies in adults have reported that $\mathrm{CCO}_{2} \mathrm{R}$ is preserved during desflurane anesthesia. ${ }^{2-4}$ In children, the effects of desflurane on $\mathrm{CCO}_{2} \mathrm{R}$ are not as well defined. In a study of ten children, ${ }^{4}$ cerebral blood flow velocity (CBFV) was recorded during the first ten minutes of desflurane administration while the $\mathrm{EtCO}_{2}$ was changed from 40 to $30 \mathrm{mmHg}$. Based on their observations, the authors suggested that $\mathrm{CCO}_{2} \mathrm{R}$ is preserved during desflurane anesthesia. However, the lack of steady state conditions might have limited the identification of the cerebrovascular effects of desflurane on the $\mathrm{CCO}_{2} \mathrm{R}$.

This study was designed to determine the effects of two different desflurane concentrations on the $\mathrm{CCO}_{2} \mathrm{R}$ in children at hypo-, normo- and hypercapnia.

\section{Methods}

After approval by the Institutional Research Ethics Board and written informed parental consent, 16 unpremedicated children aged two to six years, ASA I or II, undergoing elective urological surgery were enrolled. Children with a history of prematurity, cardiac, pulmonary, or neurological disease, or a contraindication to regional anesthesia were excluded from the study.

Anesthesia was induced by facemask with sevoflurane in oxygen. Standard monitoring included electrocardiogram, pulse oxymetry, non-invasive arterial blood pressure, and a nasopharyngeal temperature probe. A peripheral venous cannula was inserted and orotracheal intubation facilitated with rocuronium $1.0 \mathrm{mg} \cdot \mathrm{kg}^{-1}$. Immediately after tracheal intubation, sevoflurane was discontinued and intermittent positive pressure ventilation (IPPV) with desflurane in air/oxygen $\left(\mathrm{FIO}_{2}=\right.$ 0.35 ) with a fresh-gas flow of $3 \mathrm{~L} \cdot \mathrm{min}^{-1}$ was initiated, using a circle system and an Air-Shields ventilator (AirShields Vickers®, Hatboro, USA). Peak inspiratory pressures were kept at $20 \mathrm{mmHg}$ and the respiratory rate was adjusted to achieve an initial end-tidal $\mathrm{CO}_{2}$
$\left(\mathrm{EtCO}_{2}\right)$ of $30 \mathrm{mmHg}$. No positive end- expiratory pressure was used at any time during the study period. Exogenous $\mathrm{CO}_{2}$ was administered to achieve $\mathrm{EtCO}_{2}$ levels of 40 and $50 \mathrm{mmHg}$. EtCO $\mathrm{Cas}_{2}$ measured using a central venous catheter (Intracath 19 Gauge, $30.5 \mathrm{~cm}$, Becton-Dickinson ${ }^{\circledR}$, Sandy, USA) advanced to the distal tip of the endotracheal tube. The desflurane concentration, fraction of inspired oxygen concentration $\left(\mathrm{F}_{\mathrm{i}} \mathrm{O}_{2}\right)$ and $\mathrm{EtCO}_{2}$ were continuously analyzed with a Capnomac Ultima monitor (Datex Instruments Corporation ${ }^{\circledR}$, Helsinki, Finland). A caudal epidural block with $1.0 \mathrm{~mL} \cdot \mathrm{kg}^{-1}$ of plain bupivacaine $0.25 \%$ was performed for each patient. Surgery was allowed to commence 15 min after the caudal block had been performed and the block was assumed to be successful if upon skin incision the heart rate and mean arterial pressure did not increase more than 5\% from baseline (immediately before skin incision). All children were kept supine and horizontal throughout the study period. Normothermia was maintained using a conductive water mattress (Gaymar ${ }^{\circledR} \mathrm{T} /$ Pump, Gaymar Industries, New York, USA) and/or convective forced air-warming system (Bair Hugger ${ }^{\circledR}$, Augustine Medical Inc., Eden Prairie, USA).

The transcranial Doppler (TCD) probe was placed over the right temporal window and adjusted to insonate the Ml segment of the middle cerebral artery (MCA) to measure systolic and mean cerebral blood flow velocity (Vmca). A pulse-gated TCD with a 2$\mathrm{MHz}$ emitted ultrasonic frequency (Neuroguard, Medasonics ${ }^{\circledR}$, Fremont, USA) was used and the Doppler shift data was processed and displayed by a real-time spectral analyzer. A custom made wheel was used to fix the TCD-probe to the patient's head to keep the angle of insonation constant. ${ }^{5}$

Patients were randomized to the order of desflurane concentration (1.0 and 1.5 age-adjusted $\mathrm{MAC})^{6}$ as well as to the sequence of the $\mathrm{EtCO}_{2}$ concentration $(30,40$ and $50 \mathrm{mmHg}$ ) using computer generated random number tables. Fifteen minutes were allowed to reach steady state after changing the desflurane concentration and five minutes after changing the $\mathrm{EtCO}_{2}$ concentration. At each $\mathrm{EtCO}_{2}$ level, three measurements were recorded at one- minute intervals. Vmca, heart rate (HR), mean arterial pressure (MAP), $\mathrm{EtCO}_{2}$ and desflurane concentrations were simultaneously measured. After the desflurane concentration was changed, the same sequence of $\mathrm{EtCO}_{2}$ concentrations was repeated.

Demographic and parametric data are expressed as mean \pm SD. The number of patients needed to demonstrate a direct effect on CBFV was calculated with the assumption that a $20 \%$ change in Vmca would be clini- 
cally relevant. Based on a statistical power of 0.8 , an $\alpha_{2}=$ 0.05 and $\mathrm{a}=0.2$, seven patients were suggested. A total of 16 patients were studied to account for methodological difficulties that could have led to exclusion from the study. Vmca, HR and MAP were analyzed with repeated measures ANOVA and Tukey-Kramer HC for multiple comparisons. The Vmca data files were stored on a computer (Apple Macintosh $®$, Cupertino, USA) and later analyzed by an investigator unaware of the randomization and the hemodynamic response. A $P<0.05$ was accepted for statistical significance.

\section{Results}

Sixteen patients were studied, with a mean age and weight of $3.5 \pm 1.5 \mathrm{yr}$ and $14.4 \pm 3.1 \mathrm{~kg}$, respectively. The caudal block was successful in all cases and TCD measurements were completed in all children. MAP remained stable throughout the study period. At both desflurane concentrations, the increase in $\mathrm{EtCO}_{2}$ from 30 to $40 \mathrm{mmHg}$ did not affect the HR, however it decreased significantly at $50 \mathrm{mmHg}(P<0.05)$.

At 1.0 age-adjusted MAC desflurane, increasing EtCO from 30 to $40 \mathrm{mmHg}$ resulted in an increase in Vmca from $58 \pm 14 \mathrm{~cm} \cdot \mathrm{sec}^{-1}$ to $72 \pm 16 \mathrm{~cm} \cdot \mathrm{sec}^{-1}(P<$ $0.05)$, however, it did not increase further between 40 and $50 \mathrm{mmHg}\left(72 \pm 16 \mathrm{~cm} \cdot \mathrm{sec}^{-1}\right.$ to $73 \pm 17 \mathrm{~cm} \cdot \mathrm{sec}^{-1}$; Figure). When $\mathrm{EtCO}_{2}$ was increased from 30 to 40 $\mathrm{mmHg}$ at 1.5 age-adjusted MAC desflurane, Vmca did not change significantly (from $51 \pm 16 \mathrm{~cm} \cdot \mathrm{sec}^{-1}$ to $59 \pm$ $\left.11 \mathrm{~cm} \cdot \mathrm{sec}^{-1}\right)$, but at $50 \mathrm{mmHg} \mathrm{EtCO}_{2}$, Vmca increased significantly (to $66 \pm 13 \mathrm{~cm} \cdot \mathrm{sec}^{-1}$ ) when compared to $30 \mathrm{mmHg}(P<0.05$; Figure $)$.

At 1.0 MAC desflurane, the $\mathrm{CCO}_{2} \mathrm{R}$ expressed as the percent change in mean $\mathrm{CBFV}$ per $1 \mathrm{mmHg}$ change in $\mathrm{EtCO}_{2}$ was 2.45 between 30 and $40 \mathrm{mmHg}$ and 0.14 between 40 and $50 \mathrm{mmHg}$. At 1.5 MAC, the corresponding values were 1.56 and 1.25 , respectively.

There were no complications as a result of this study.

\section{Discussion}

This study suggests that cerebrovascular reactivity to $\mathrm{CO}_{2}$ is preserved at hypocapnia in children anesthetized with 1.0 MAC desflurane, but is reduced at 1.5 MAC. The expected increase in Vmca associated with hypercapnia seems attenuated, suggesting that desflurane may maximally dilate the cerebral vasculature and that the addition of $\mathrm{CO}_{2}$ does not contribute to further increases in Vmca.

A previous study in children comparing three different desflurane concentrations showed a significantly increased Vmca at 1.0 MAC when compared to 0.5 MAC desflurane, without any further increases at $\mathbf{1 . 5}$

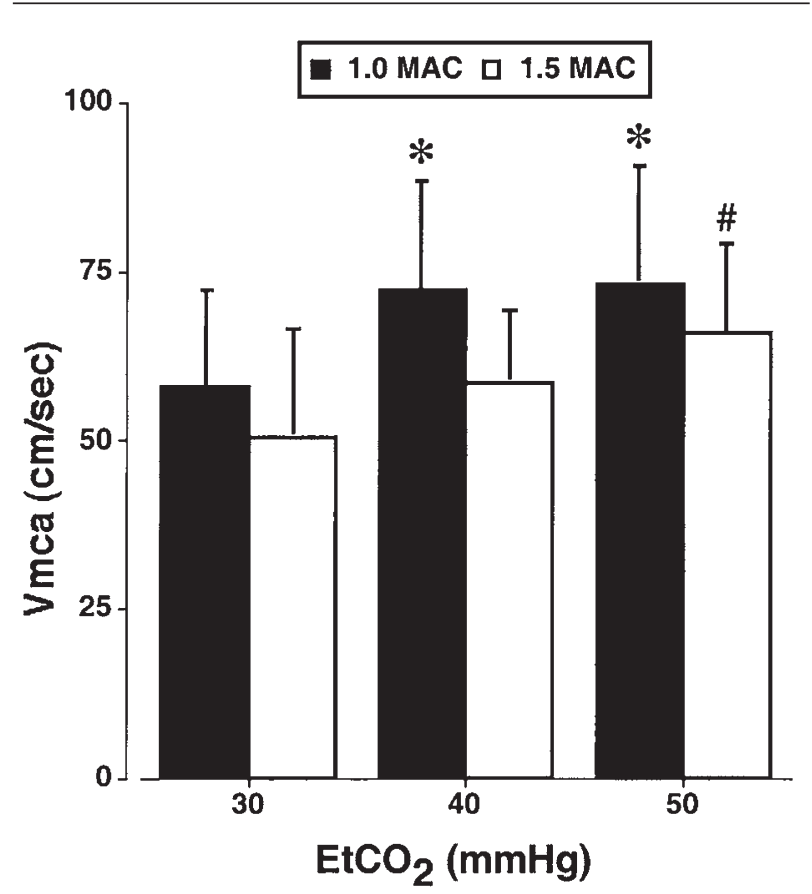

FIGURE Cerebral blood flow velocity in the middle cerebral artery (Vmca) at different desflurane and $\mathrm{EtCO}_{2}$ concentrations. * denotes a significant increase in $\mathrm{Vmca}$ when compared to baseline (30 $\left.\mathrm{mmHg} \mathrm{EtCO}_{2} ; P<0.05\right)$; \# indicates a significant change when compared to baseline $\left(30 \mathrm{mmHg} \mathrm{EtCO}_{2} ; P<0.05\right)$.

MAC. ${ }^{7}$ These observations support the concept that cerebral vasodilatation in children is already maximal during anesthesia with 1.0 MAC desflurane at normocapnia. These findings are not supported by a previous study in adults reporting that desflurane caused further cerebral vasodilatation at 1.5 MAC when compared to 0.5 MAC. ${ }^{8}$ However, propofol was used to induce cerebral isoelectricity before the addition of desflurane. It is therefore very likely that the cerebral vessels were already vasoconstricted due to propofol and that the net effect of desflurane resulted in cerebral vasodilatation.

In the present study, the small differences in CBFV observed between 1.0 and 1.5 MAC desflurane at all three $\mathrm{EtCO}_{2}$ concentrations could be explained by the "dual action hypothesis". 9,10 The authors of these studies have suggested that desflurane causes a direct cerebral arterial vasodilatation independent of cerebral metabolism, even though desflurane keeps the flowmetabolism coupling intact. The reduction in cerebral metabolic rate of oxygen $\left(\mathrm{CMRO}_{2}\right)$ associated with deeper anesthesia means that desflurane also causes 
cerebral vasoconstriction. Therefore, what is measured clinically is the result of a subtle balance between these two antagonizing effects. It is possible that at the higher desflurane concentration the cerebral vasconstriction as a result of the decreased $\mathrm{CMRO}_{2}$ becomes more prominent, as suggested by Mielck et al. ${ }^{3}$ In that study, $\mathrm{CCO}_{2} \mathrm{R}$ was preserved at 1.0 MAC desflurane.

A recent study with 1.0 age-adjusted MAC sevoflurane in children reported $\mathrm{CCO}_{2} \mathrm{R}$ values of $8.6 \% / \mathrm{mmHg}$ from 25 to $35 \mathrm{mmHg}$ and $5.1 \% / \mathrm{mmHg}$ from 35 to $45 \mathrm{mmHg} .{ }^{11}$ These authors also demonstrated a loss of $\mathrm{CCO}_{2} \mathrm{R}$ at hypercapnia. Although the $\mathrm{EtCO}_{2}$ intervals were slightly different in that study, these values are considerably greater and reflect the well preserved $\mathrm{CCO}_{2} \mathrm{R}$ during sevoflurane anesthesia. This implies that changes in $\mathrm{P}_{\mathrm{a}} \mathrm{CO}_{2}$ result in more pronounced changes in cerebral vasculature in children anesthetized with sevoflurane than with other inhalational anesthetics. The $\mathrm{CCO}_{2} \mathrm{R}$ for isoflurane and halothane in the range of 20 to $40 \mathrm{mmHg}$ were reported as 2.6 and $1.4 \% / \mathrm{mmHg}$, respectively. ${ }^{12}$

Desflurane and isoflurane showed similar effects with respect to $\mathrm{CCO}_{2} \mathrm{R}$ in adults when $\mathrm{CBF}$ and $\mathrm{CCO}_{2} \mathrm{R}$ were measured by $i{ }^{133}$ Xenon. ${ }^{2}$ Although the authors only examined the $\mathrm{CCO}_{2} \mathrm{R}$ at 25 and 35 $\mathrm{mmHg} \mathrm{P}_{\mathrm{a}} \mathrm{CO}_{2}$, they reported that $\mathrm{CCO}_{2} \mathrm{R}$ at 1.0 MAC desflurane and isoflurane is maintained at about 1.3 to $1.6 \% / \mathrm{mmHg}$. Mielck et al. ${ }^{3}$ used a modified Kety-Schmidt saturation technique with argon as inert tracer gas to measure CBF in adults and suggested that $\mathrm{CCO}_{2} \mathrm{R}$ is preserved at 1.0 MAC desflurane between an $\mathrm{EtCO}_{2}$ of 30 and $50 \mathrm{mmHg}$.

In a recent pediatric study, Brenet et al. ${ }^{4}$ concluded from ten children that $\mathrm{CCO}_{2} \mathrm{R}$ remains intact at 1.0 age- adjusted MAC desflurane. However, the children received propofol, atropine, fentanyl, and atracurium for induction of anesthesia and tracheal intubation. Within the first minute following tracheal intubation and administration of desflurane, baseline CBFV measurements were recorded and subsequent recordings were obtained every minute for the next ten minutes. One may speculate that a state of hyperdynamic circulation was still present, that the cerebral vasoconstrictive effect of propofol was most likely still in effect and that the brain partial pressure of desflurane had reached a steady state only at the end of the study period. It has also been demonstrated that rapid increases in desflurane concentration stimulate the sympathetic nervous system ${ }^{13-15}$ and a period of up to nine minutes is necessary to abate this effect. ${ }^{16}$ Although fentanyl has been shown to attenuate the cardiovascular stimulation triggered by desflurane in adults, ${ }^{17}$ the situation remains unclear in children. To prevent the addition of confounding factors, neither opioids nor atropine were used in the present study.

All patients received sevoflurane for induction of anesthesia. With a brain/blood partition coefficient of $1.7,{ }^{18}$ the calculated time constant for equilibration in the grey matter of the brain is approximately $3.4 \mathrm{~min}$, thus the time to $98 \%$ equilibration of the anesthetic partial pressure (i.e., four time constants) equals 13.6 min. After discontinuation of sevoflurane, we allowed 15 min for elimination of sevoflurane.

The equilibration time constant for desflurane within the brain has been calculated as about 2.6 min. ${ }^{18}$ Fifteen minutes were allowed between changes in the desflurane concentration and before recording the first CBFV measurement in order for steady state to be reached. The time constant for the acute effects of carbon dioxide on cerebral arteries is approximately one minute. ${ }^{19}$ In the present study five minutes were allowed to reach equilibration within the brain. Measurements of $\mathrm{EtCO}_{2}$ were used to estimate $\mathrm{P}_{\mathrm{a}} \mathrm{CO}_{2}$. In healthy children, it has been shown that EtCO ${ }_{2}$ closely approximates $\mathrm{P}_{\mathrm{a}} \mathrm{CO}_{2} \cdot{ }^{20}$ The accuracy of the $\mathrm{EtCO}_{2}$ measurement was increased using a central venous catheter advanced inside of the endotracheal tube (ETT) adjusted to allow sampling from the distal end of the ETT. ${ }^{21}$

Changes in intrathoracic pressure have a direct effect on cerebral venous pressure and may alter cerebral perfusion pressure. ${ }^{22}$ In order to eliminate this source of error, IPPV was maintained constant and exogenous $\mathrm{CO}_{2}$ was administered within the fresh gas flow instead of altering the respiratory rate or the tidal volume to achieve the different $\mathrm{EtCO}_{2}$ levels.

TCD was used to measure changes in CBFV and consequently $\mathrm{CBF}$ non-invasively. Previous studies have suggested that the diameter of the MCA remains constant during anesthesia ${ }^{23,24}$ and that changes in Vmca accurately reflect changes in cerebral blood flow. $^{25-28}$ Standard measures for CBF correlate well with CBFV data obtained by TCD in both adults and neonates. ${ }^{28-30}$ The insonating angle, i.e., the angle between the ultrasonic beam and the insonated vessel axis, was kept constant throughout the study by using a custom made wheel to fix the TCD probe to the patient's head. ${ }^{5}$

In conclusion, desflurane anesthesia in combination with mild hyperventilation seems to maintain $\mathrm{CCO}_{2} \mathrm{R}$ at 1.0 MAC. However, at 1.5 MAC, the effect of hypocapnia on $\mathrm{CCO}_{2} \mathrm{R}$ is reduced, probably due to the potent vasodilatatory effect of desflurane. This is also emphasized by the reduction in $\mathrm{CCO}_{2} \mathrm{R}$ reported in this study at hypocapnia when compared with the values previously reported for sevoflurane. In children with an increased 
ICP the potential benefits of desflurane anesthesia should be weighed carefully against the risks.

\section{Acknowledgements}

The authors would like to thank Dr. M.J. Fredrickson for his assistance with data acquisition. We are also grateful to Mr. K. Matthews, RRT, for his assistance in the study, and to Dr. B. A. Kashin, Corporate Chief of Anesthesia at the William Osler Health Care Center, Brampton, Dr. V. Chang, Site Chief of Anesthesia at the Etobicoke Hospital Campus, and Mr. G. Main, Biomedical Engineering for providing the desflurane vaporizer. We would also like to express our thanks to our colleagues from the Department of Surgery, Division of Urology and the Operating Room nurses for their assistance with this study.

\section{References}

1 Severinghaus JW, Lassen N. Step hypocapnia to separate arterial from tissue $\mathrm{PCO}_{2}$ in the regulation of cerebral blood flow. Circ Res 1967; 20: 272-8.

2 Ornstein E, Young WL, Fleischer LH, Ostapkovich N. Desflurane and isoflurane have similar effects on cerebral blood flow in patients with intracranial mass lesions. Anesthesiology 1993; 79: 498-502.

3 Mielck F, Stephan H, Bubre W, Weyland A, Sonntag H. Effects of 1 MAC desflurane on cerebral metabolism, blood flow and carbon dioxide reactivity in humans. $\mathrm{Br}$ J Anaesth 1998; 81: 155-60.

4 Brenet O, Granry JC, Poirier N, Le Gall R. The effect of desflurane on cerebral blood flow velocity and cerebrovascular reactivity to $\mathrm{CO} 2$ in children (French). Ann Fr Anesth Reanim 1998; 17: 227-33.

5 Bissonnette B, Benson LN. Closure of persistently patent arterial duct and its impact on cerebral circulatory haemodynamics in children. Can J Anaesth 1998; 45: 199-205.

6 Taylor RH, Lerman J. Minimum alveolar concentration of desflurane and hemodynamic responses in neonates, infants, and children. Anesthesiology 1991; 75: 975-9.

7 Luginbuebl IA, Fredrickson MJ, Bissonnette B. Desflurane anesthesia affects cerebral blood flow velocity in young children. Anesthesiology 2001; 95: Al275 (abstract).

8 Matta BF, Mayberg TS, Lam AM. Direct cerebrovasodilatory effects of halothane, isoflurane, and desflurane during propofol-induced isoelectric electroencephalogram in humans. Anesthesiology 1995; 83: 980-5.

9 Hansen TD, Warner DS, Todd MM, Vust LJ. The role of cerebral metabolism in determining the local cerebral blood flow effects of volatile anesthetics: evidence for persistent flow-metabolism coupling. J Cereb Blood
Flow Metab 1989; 9: 323-8.

10 Drummond JC, Todd MM, Scheller MS, Shapiro HM. A comparison of the direct cerebral vasodilating potencies of halothane and isoflurane in the New Zealand white rabbit. Anesthesiology 1986; 65: 462-7.

11 Rowney DA, Fairgrieve R, Bissonnette B.

Cerebrovascular carbon dioxide reactivity in children anaesthetized with sevoflurane. Br J Anaesth 2002; 88: 357-61.

12 Leon JE, Bissonnette B. Cerebrovascular responses to carbon dioxide in children anaesthetized with halothane and isoflurane. Can J Anaesth 1991; 38: 817-25.

13 Pagel PS, Kampine JP, Schmeling WT, Warltier DC. Comparison of the systemic and coronary hemodynamic actions of desflurane, isoflurane, halothane, and enflurane in the chronically instrumented dog. Anesthesiology 1991; 74: 539-51.

14 Weiskopf RB, Moore MA, Eger EI II, et al. Rapid increase in desflurane concentration is associated with greater transient cardiovascular stimulation than with rapid increase in isoflurane concentration in humans. Anesthesiology 1994; 80: 1035-45.

15 Moore MA, Weiskopf RB, Eger EI II, Noorani M, McKay L, Damask M. Rapid 1\% increases of end-tidal desflurane concentration to greater than $5 \%$ transiently increase heart rate and blood pressure in humans. Anesthesiology 1994; 81: 94-8.

16 Ebert TJ, Muzi M. Sympathetic hyperactivity during desflurane anesthesia in healthy volunteers. A comparison with isoflurane. Anesthesiology 1993; 79: 444-53.

17 Weiskopf RB, Eger EI II, Noorani M, Daniel M. Fentanyl, esmolol, and clonidine blunt the transient cardiovascular stimulation induced by desflurane in humans. Anesthesiology 1994; 81: 1350-5.

18 rasuda N, Targ AG, Eger EI II. Solubility of I-653, sevoflurane, isoflurane, and halothane in human tissues. Anesth Analg 1989; 69: 370-3.

19 Bode H. Physiological influences on cerebral hemodynamics. In: Bode H. Pediatric Applications of Transcranial Doppler Sonography. Wien: SpringerVerlag; 1988: 84-93.

20 Bissonnette B, Lerman J. Single breath end-tidal $\mathrm{CO}_{2}$ estimates of arterial $\mathrm{PCO}_{2}$ in infants and children. Can J Anaesth 1989; 36: 110-2.

21 Badgwell JM, Heavner JE. End-tidal carbon dioxide pressure in neonates and infants measured by aspiration and flow-through capnography. J Clin Monit 1991; 7: 285-8.

22 Dresser LP, McKinney WM. Anatomic and pathophysiologic studies of the human internal jugular valve. Am J Surg 1987; 154: 220-4.

23 Giller CA, Bowman G, Dyer H, Mootz L, Krippner W. 
Cerebral arterial diameters during changes in blood pressure and carbon dioxide during craniotomy. Neurosurgery 1993; 32: 737-41; discussion 741-2.

24 Huber P, Handa J. Effect of contrast material, hypercapnia, hyperventilation, hypertonic glucose and papaverine on the diameter of the cerebral arteries. Angiographic determination in man. Invest Radiol 1967; 2: 17-32.

25 Dahl A, Lindegaard KF, Russell D, et al. A comparison of transcranial Doppler and cerebral blood flow studies to assess cerebral vasoreactivity. Stroke $1992 ; 23$ : 15-9.

26 Kochs E, Hoffman WE, Werner C, Albrecht RF, Schulte am Esch J. Cerebral blood flow velocity in relation to cerebral blood flow, cerebral metabolic rate for oxygen, and electroencephalogram analysis during isoflurane anesthesia in dogs. Anesth Analg 1993; 76: 1222-6.

27 Newell DW, Aaslid R, Lam A, Mayberg TS, Winn HR. Comparison of flow and velocity during dynamic autoregulation testing in humans. Stroke 1994; 25 : 793-7.

28 Bishop CCR, Powell S, Rutt D, Browse NL. Transcranial Doppler measurement of middle cerebral artery blood flow velocity: a validation study. Stroke 1986; 17 : 913-5.

29 Greisen G, Johansen K, Ellison PH, Fredriksen PS, Mali J, Friis-Hansen B. Cerebral blood flow in the newborn infant: comparison of Doppler ultrasound and ${ }^{133}$ xenon clearance. J Pediatr 1984; 104: 411-8.

30 Risberg J, Smith P. Prediction of hemispheric blood flow from carotid velocity measurements. A study with the Doppler and ${ }^{133} \mathrm{Xe}$ inhalation techniques. Stroke 1980; 11: 399-402. 